\title{
E-CRM Mobile Applications To Improve Customer Loyalty (Case Study: PT Supermal Karawaci)
}

\section{Author Notification} 13 September 2019

Final Revised

11 November 2019

Padeli $^{1}$, Mulyati $^{2}$, Muhammad Faisal ${ }^{3}$, Siska Debora ${ }^{4}$

1,2,3,4 University of Raharja, Jl. Jenderal Sudirman No.40 Modern Cikokol Tangerang e-mail: padeli@raharia.info, mulyati@raharia.info, m.faisal@raharia.info, siska.debora@raharia.info
Published

27 December 2019

\section{To cite this document:}

Padeli, Mulyati, Faisal, M., \& Debora, S. (2019). E-CRM Mobile Applications To Improve Customer Loyalty (Case Study: PT Supermal Karawaci). Aptisi Transactions On Management (ATM), 4(1), 4148.

DOI:

http://ijc.ilearning.co/index.php/ATM/article/view/1083

\begin{abstract}
Disruptive Technology is one of the backbones of Indutry4.0, In this era the company's large size is no longer a guarantee. Speed in adapting to the development and behavior of consumers is the main key. Therefore, companies must be sensitive and do self-introspection so they can detect their position in the midst of the development of science and technology in order to maintain their existence and have the opportunity to dominate the market. PT Supermall Karawaci, which is engaged in the retail business, needs to adapt and understand this rapid technological development, so for this business sector requires interaction with customers. The current system is good, but in some procedures that make customer service less than optimal and will be better if there is an effort so that customer loyalty can increase and of course the company's profit will increase. Therefore, the writers make this problem as a foundation in research and application development (E-CRM), the writers use the method of observation, elicitation, SWOT, Unified Modeling Language (UML), prototype and black box as methods of data collection, analysis, design and testing. For design, programming, web server and database, the writer uses Adobe XD applications, Android Studio, PHP, XAMPP and Microsoft SQL Server.
\end{abstract}

Keywords: Mobile devices, loyalty, interaction, customers

\section{Introduction}

In this Indutri 4.0 era, now customers behave according to the times, which want fast, accurate, and highquality services. This behavior must be understood and anticipated by companies who interact a lot with customers, because their satisfaction and loyalty is very valuable. Moreover, if a company has gained the trust of a customer, the most difficult thing ahead is to continue to maintain trust, satisfaction and improve it in a sustainable manner.

This basic need that underlies, the need for a system that can overcome this problem. Eventually a system called Customer Relationship Management was created or abbreviated as CRM. However, digital developments are making the renewal of this CRM system, and creating a CRM with a touch of Information Technology called Electronic Customer Relationship Management (E-CRM).

PT Supermal Karawaci is a company engaged in the retail mall management business, since 1992 until now, managing the allocation of tenants, complex resources, and also managing the most important things, namely maintaining relationships with customers who have existed for years. Until now, the application to manage (analyze) and analyze complex sources from various sources, especially customer data, has been running well on a website-based system. However, there are some procedures that have flaws in the use of procedures that run between the VIP Member's customers and the Management. 
Based on the explanation that the writer has explained above, the writer tries to update some system flow that runs between the procedures of the web-based E-CRM system and the SKMob Android-based application by focusing on the Redeem Point of the Author's Customer, the writer makes a design of the Mobile E-CRM Application for PT Supermal Karawaci can increase Customer Loyalty.

\subsection{The scope of research}

Because of the wide scope of problems and functionality of the existing system as well as to focus the scope of the discussion so that the focus is in the direction of the discussion in this report, the writers only limit the discussion of the problem to the Redeem Customer Point process which involves several core functions that are related in its flow scenario. This research focuses only within the Department of Customer Experience Development (CED).

\subsection{Research Objectives and Benefits}

The objectives of this study are as follows:

1. Analyze the shortcomings of the running system procedures so that can be improved and the advantages that can be increased again to be more efficient.

2. Looking for the best potential from developing some of the existing system gaps so that it has an impact on the company's revenue and profits.

3. Designing an Android-based E-CRM system that can increase customer loyalty.

The benefits generated are:

1. Add and increase customer satisfaction in dealing with PT Supermal Karawaci.

2. Increase profits and benefits from increasing VIP Member loyalty.

3. Creating more effective and efficient procedures so that the productivity of various related fields will also increase.

\section{Research Method}

\subsection{Observation Method}

Conduct observations and carry out systematic recording of the elements studied, and researchers conduct a direct review to PT Supermal Karawaci. In this way, the whiter can see clearly what the problems are happen.

\subsection{Literature Study Methods}

Conduct library studies to get more accurate data by collecting theoretical data sourced from lecture results, literature from library book collections, and other sources related to the preparation of this thesis.

\subsection{Design Method}

In this study, the design method used to assist the development and flow of program data is the Unified Modeling Language (UML) model. This model really helps a developer in making specifications, construction, visualization and documentation of a software system. The application used is Visual Paradigm version 14.2s.

\section{Results and Analysis}

\subsection{Definition of Mobile Applications}

"Application software is a subclass of computer software that utilizes the ability of a computer directly to perform a task desired by users" Wyzer (2016: 2).

\subsection{Definition of E-CRM}

According to Turbban Dewi et al (2015: 33) defines that E-CRM is a CRM system that is applied with the touch of the latest information technology developments, with several examples including web browsers, android operating systems, electronic media such as email, call centers etc., and operate using internet networks.

\subsection{E-CRM Phase}

Some phases of E-CRM according to Setiawan and Erik (2015: 35) are:

1. Acquire

This process requires the company to provide an attractive brand and view (image) to the customer so that the customer is interested in using the product / service.

2. Improve

At this stage, providing good service and also cross selling or up selling strategies can help increase customer interest in the product / service.

3. Maintain (maintain)

At this stage, customer loyalty will be gained or not depending on the company's business whether they succeed in attracting customers' hearts and defending them. 


\subsection{Definition of Loyalty}

According to Rozaqie and Kusumawati (2016: 33), "customer loyalty (sic!) Is consumer loyalty given to a product or service because it has provided a positive and valuable experience for itself".

\subsection{Definition of Android}

According to Supardi (2015: 1) is "Android is a Linux-based operating system that is used for cellular phones (mobile), such as smartphones (Smartphones) and Tablet Computers (PDAs)".

\subsection{Literature Review}

Some of the previous studies the writers have analyzed to perfect this E-CRM application are as follows:

1. Research by Rachmat Hidayat (2014) entitled "Goods Expedition Information System Using the E-CRM Method to Improve Customer Service". PT. Zima creates a desktopbased e-CRM system for conducting customer transactions and websites to get information related to customer transactions. So the company can better monitor customer relationships.

2. Research conducted by Dwianto Setiawan, Erik Hadi Saputra (2015) entitled "The Implementation of Web-Based Customer Relationship Management (CRM) Concepts on Ud Toyoriz Busindo" solves the problem of UD Toyoriz Busindo CRM systems whose systems have not yet optimized analytical and operational systems, so that affects the performance of the company. For that the writers implement additional features on the running CRM system.

3. Research conducted by Demo et al (2017) entitled "Customer Relationship Management Scale for the B2C Market: A Cross-Cultural Comparison" where the purpose of this study is to validate the Customer Relationship Management Scale (CRMS) in France, and to compare French models with those in Brazil and America. The results obtained in the analysis can be concluded that the relationship between client and company is two dimensions and involves two different factors, namely Loyalty and Customer Service.

\subsection{Designing E-CRM}

The procedure flow for the Android-based customer redeem point application is as follows:

1. Nonmember customers can use the application by first having to register on the application. Nonmember customers can sign in to the application but cannot use the redeem point feature.

2. New non-member customers who register in the application, must still come and confirm with Customer Service about the validity of the data input. If it has been confirmed, the customer's status becomes a customer On Progress.

3. VIP customer members and nonmember customers must shop at any tenant to get transaction receipts that can be exchanged at the Customer Service (CS) counter to be used as an addition to transactions for nonmember customers and as an input point for VIP member customers into the E-CRM based system web that is already running.

4. Customer points that have been inputted by CS will be stored in the database server on the current E-CRM system.

5. VIP member customers, can immediately sign in and check the points they have if the card is still active or on progress.

6. Points that are in the application, the customer can use to exchange benefits and rewards in accordance with the available catalog, which is provided by the management of PT Supermal Karawaci.

7. After the customer decides to exchange the points for one of the benefits / rewards available, a transaction detail screen will appear and a QR Code will appear. While the exchange status is pending.

8. To claim benefits / rewards, customers must come to Supermal Karawaci and show the QR Code to CS to confirm the exchange.

9. If the data is valid and the transaction is successful, the customer is entitled to get benefits / rewards according to what was chosen in the application and the exchange status is complete.

\subsection{Display of Proposed Programs}




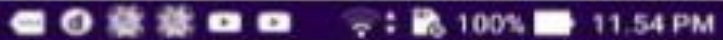

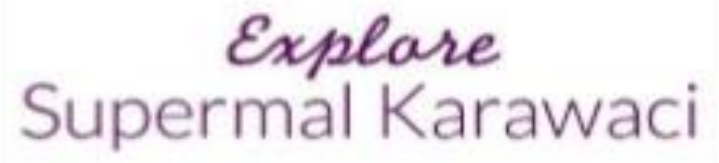

Figure 1. Display of Splashscreen UI

Note: The user interface above is the display when the application was first launched.

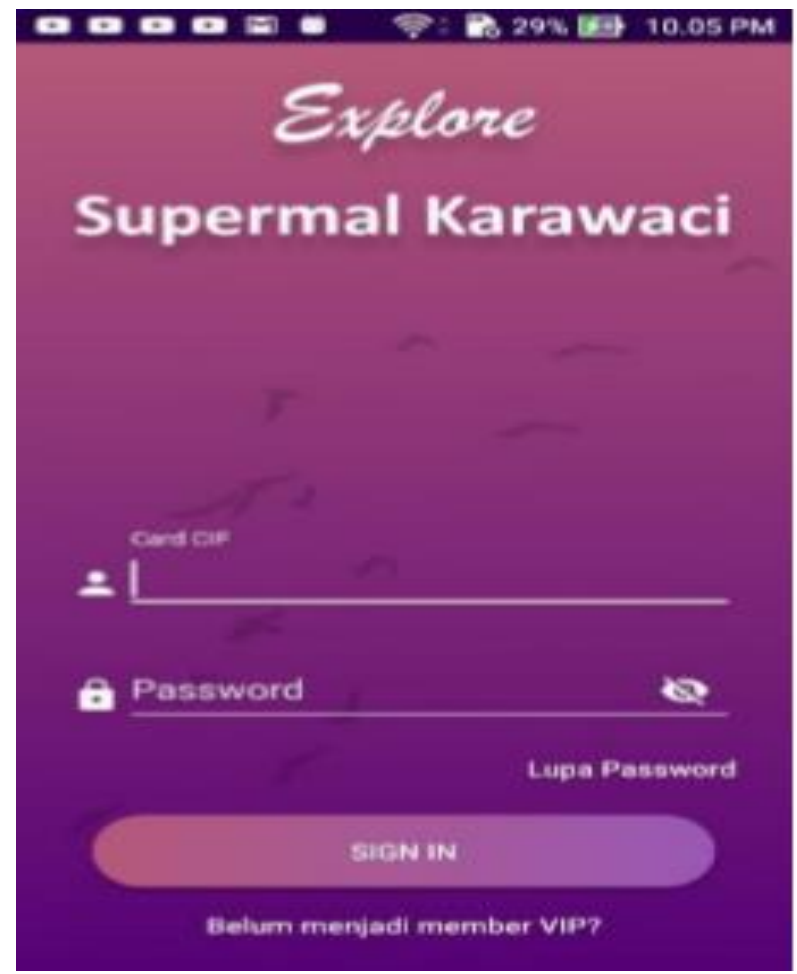

Figure 2. Display UI Sign In 
Note: The user interface above is the main display Sign In for the user after the splashscreen of Supermal Karawaci is finished.

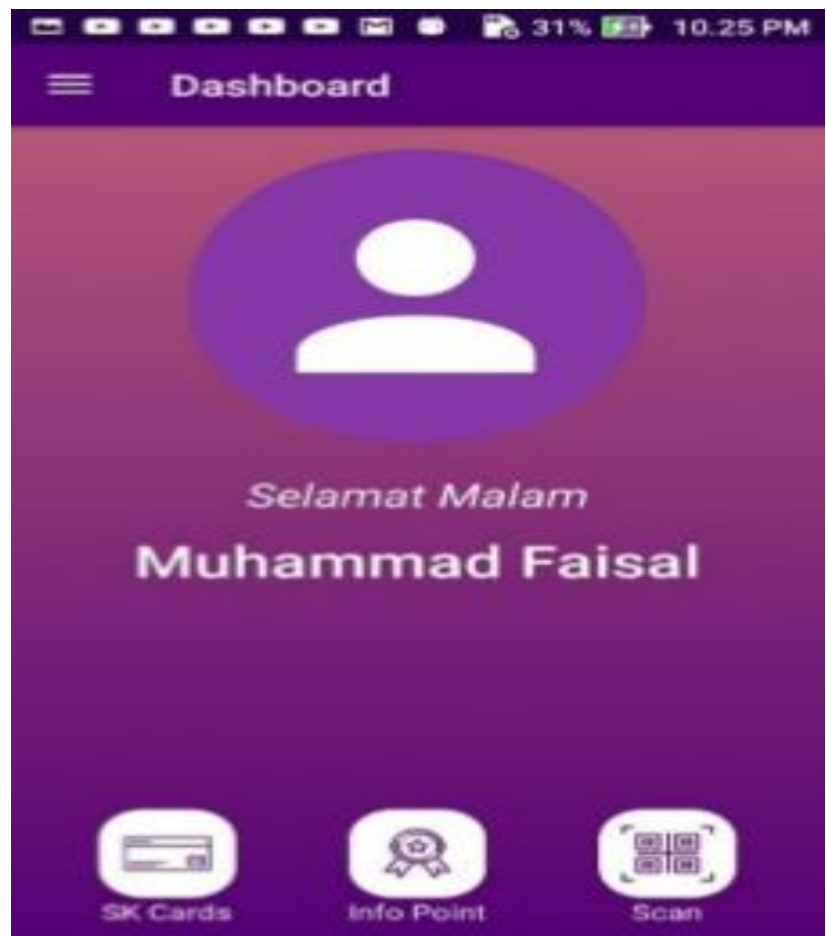

Figure 3. Display Dashboard UI (Main page)

Note: The user interface above is the main display of the dashboard after the user has successfully signed in.

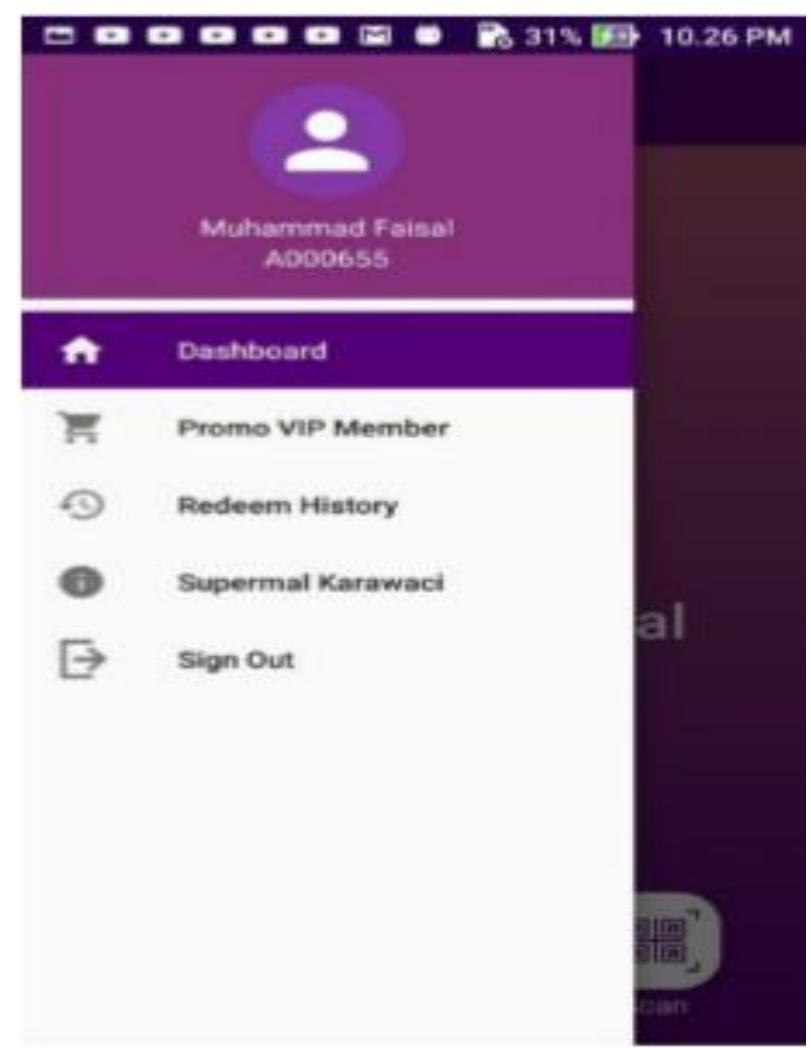

Figure 4. Display UI Side Navigation Bar 
Note: The user interface above is a side navigation drawer bar display for navigating the main functionality of the application.
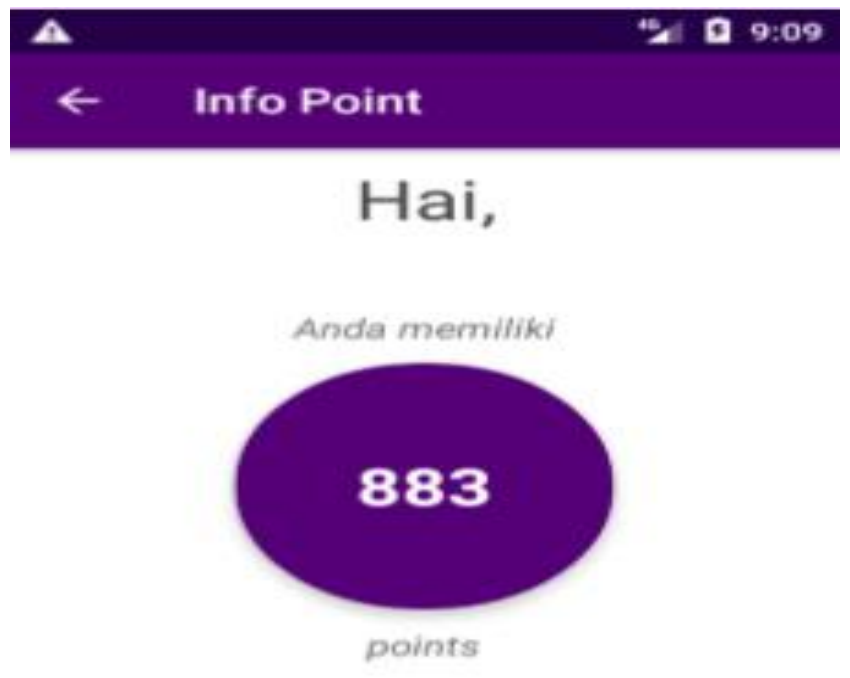

Ingin Redeem Point Anda dengan

Reward?

\section{REDEEM}

Figure 5. Display UI Info Point

Note: The user interface above is an info point display to inform the accumulated user points.
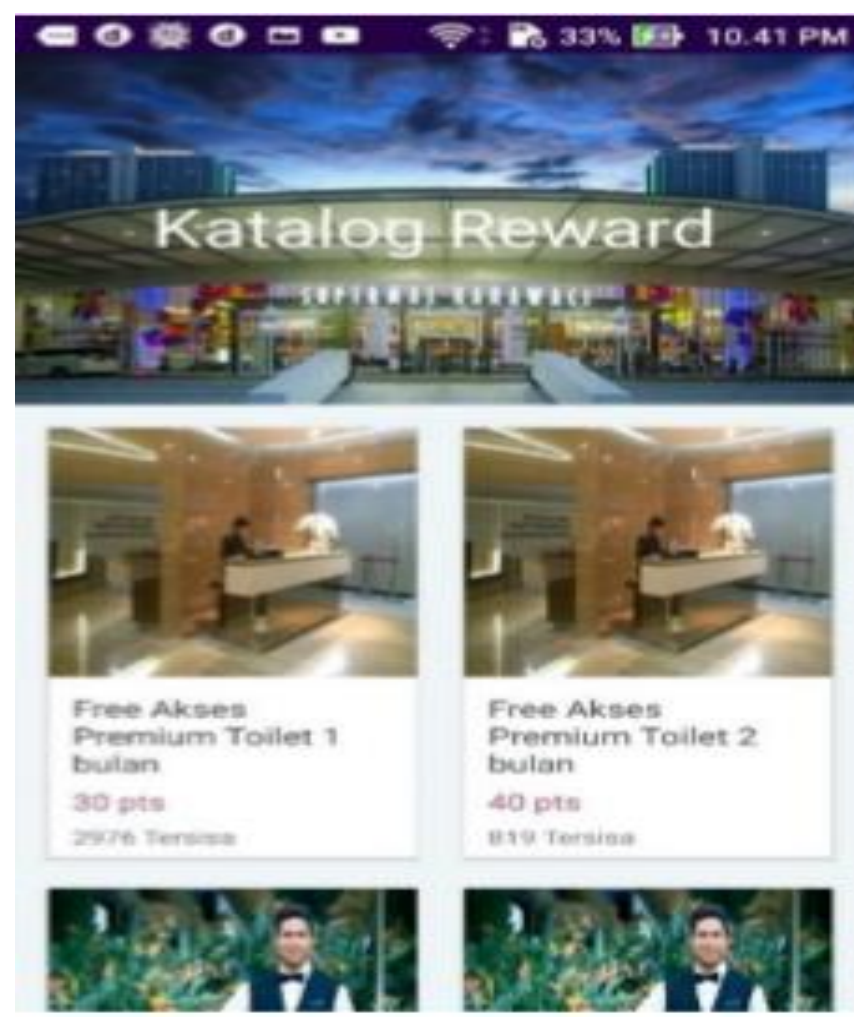

Figure 6. Display UI Reward Catalog

Note: The user interface above is the display of the reward catalog provided by Supermal Karawaci which can be redeemed by the customer. 


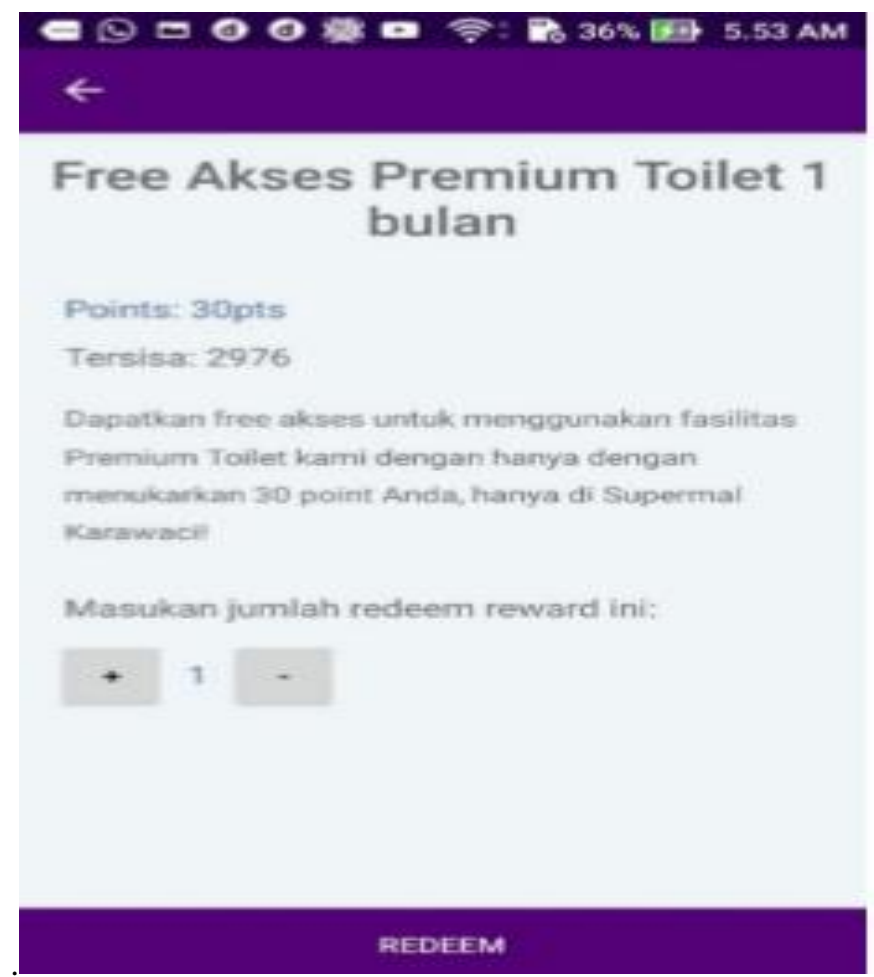

Figure 7. Display UI Reward Details Catalog

Note: On the reward reward catalog menu, customers can see information on the number of points, stock, information and the number of rewards that they want to retrieve.

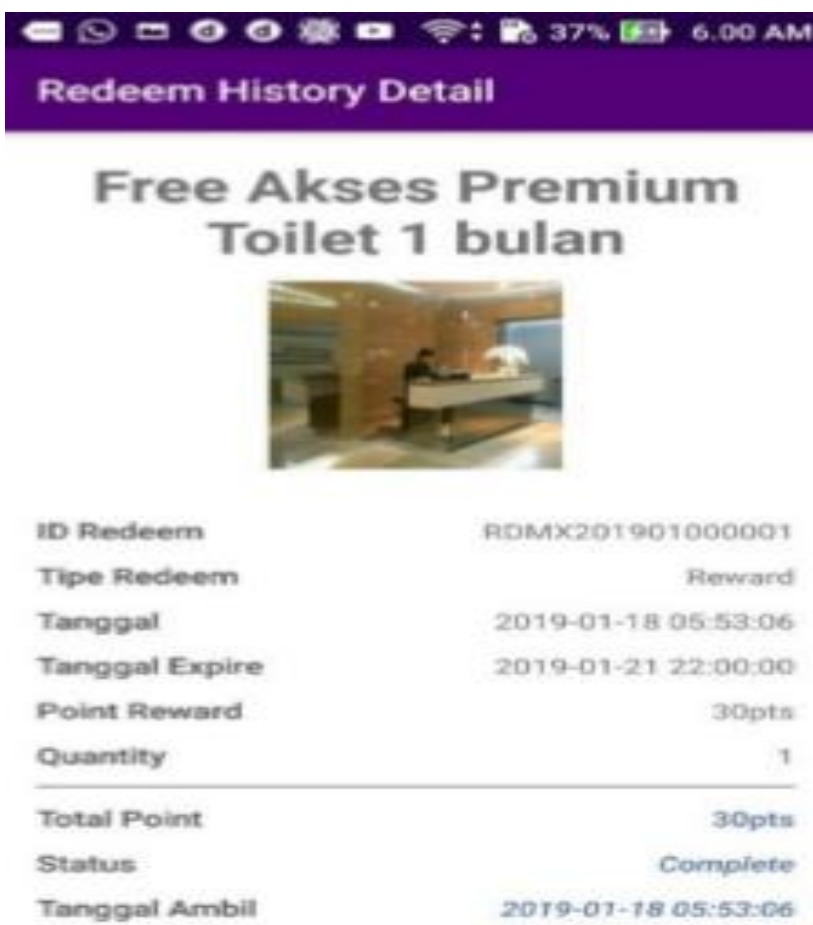

Figure 8. Display UI Redeem History Detail (Complete)

Note: The user interface above is a detailed redeem history display of completed redeem transactions. 


\section{Conclusion}

Three points that researchers can conclude and answer the whole problem statement are:

1. By making an Android-based system, to adapt to current technology, that is technology with high mobility in order to make it easier for customers. With the ease of the process, customer loyalty will increase.

2. By changing the process that can be improved by adapting an Android-based system that only requires the customer's personal cellphone.

3. By simplifying several flow and procedures system aimed at facilitating and enhancing the shopping experience, as well as customer satisfaction.

\section{References}

[1] Wyzer, Muhammad, Yusuf Durachman, and Viva Arifin. 2016. Web-based instrument sales application (case study of PT. Duta Karya Musikindo Jakarta). Informatics Study: Journal of Information Systems. Vol. 4 No. 1

[2] Dewi, Meta Amalya, Anggi Anggriani and Jaka Mahmud. 2015. Electronic Customer Relationship Management as Support for Customer Service at PT. Bintang Jasa Gemilang. SENSI Journal. Vol. 1 No. 1, 31-39.

[3] Setiawan, Dwianto, and Erik Hadi Saputra. Application of Website Based Customer Relationship Management (CRM) Concepts on Ud Toyoriz Busindo. Data Management and Information Technology (DASI), 16(1), 34.

[4] Rozaqie, S. M., and Andriani Kusumawati. 2016. Analysis of Experiential Marketing Factors and Their Effects on Customer Loyalty. Journal of Business Administration. Vol. 38 No. 1, 3039.

[5] Supardi, Yuniar. 2015. Learning Android Coding for Beginners. Jakarta: PT Elex Media Komputindo.

[6] Hidayat, Rachmat. 2014. Goods Expedition Information System Using ECRM Method to Improve Customer Service. Global Sisfotek Journal. Vol. 4 No. 2, 41-45.

[7] Demo, G., Watanabe, E. A. M., Chauvet, D. C. V., \& Rozzett, K. (2017). Customer Relationship Management Scale for the B2C Market: A Cross-Cultural Comparison. Revista de Administração Mackenzie, 18(3), 42-69. 